\title{
Successful use of size-mismatched liver allografts in children by delayed primary closure of the abdominal wall
}

\author{
A. S. SOIN, P. J. FRIEND, G. NOBLE-JAMIESON*, C. J. E. WATSON, \\ N. V. JAMIESON, R. Y. CALNE and N. BARNES*
}

University of Cambridge Clinical School, Departments of Surgery and *Paediatrics, Addenbrooke's Hospital, Cambridge, UK Correspondence to: Mr A. S. Soin, Department of Surgery, Level 9, Addenbrooke's Hospital, Hills Road, Cambridge CB2 2QQ, UK

Children who are too ill to await a liver graft of suitable size may be transplanted with a relatively oversized graft by leaving the abdominal wound partially open, the defect being bridged with polypropylene mesh and the mesh reduced in stages until it can be removed and the wound directly closed. This technique has been used in seven children who received nine grafts (five reduced and four full size). Their mean age was 7.3 (range 0.5-11) months and mean weight $5 \cdot 8$ (range $2 \cdot 3-7 \cdot 2$ ) kg. Progressive reduction in the size of the transplanted liver made primary closure possible in survivors in up to four stages. Over a follow-up period of 3 to 58 months, five of the nine grafts and five of the seven patients survived. No significant complications attributable to the technique were encountered. The technique of delayed primary abdominal wall closure may be of benefit in children at risk of graft failure because of a size-mismatched graft.
The scarcity of donor livers of appropriate size is the most important constraint on paediatric liver transplantation. Although the use of reduced-size grafts has increased the potential donor pool, there is still an appreciable waitinglist morbidity and mortality, especially in very small children'. Larger than ideal grafts may therefore have to be accepted for very sick and small children. In such cases, the authors have adopted the policy of using a mesh to achieve temporary cover of the abdominal wound without tension and allow delayed primary closure of the abdominal wall, to avoid compression of the oversized graft and thus reduce the risk of graft infarction. Experience with this technique is presented here.

\section{Patients and methods \\ Technique of delayed primary closure}

The reduced- or full-size liver graft was implanted as previously described $^{2}$. The incisior: was closed only so far as was possible without undue compression of the abdominal contents. The rest of the incision was left open and the edges of the muscle layer were sutured to a sheet of polypropylene mesh which was cut to the size of the defect. The skin edges were not apposed and the mesh was covered with a sterile occlusive dressing.

The degree of abdominal tension was assessed daily and the mesh size was reduced in stages over 1-7 weeks. This was done in the operating theatre under general anaesthesia by either excising the central portion of the mesh and suturing the edges together or trimming one side and resuturing it to the muscle layer. When the abdomen was soft enough to be closed completely, the mesh was excised and the incision closed in layers.

\section{Recipients and donors}

This technique has been used in seven children (five girls and two boys) receiving nine grafts. Their mean age was $7 \cdot 3$ (range $0 \cdot 5-11$ ) months and mean weight $5 \cdot 8$ (range $2 \cdot 3-7 \cdot 2$ ) $\mathrm{kg}$. The mean donor age was $7 \cdot 3$ (range 2-31) years and weight $21 \cdot 1$

Paper accepted 12 January 1996 (range 11-50) kg. Five grafts were reduced and four were full size. The details of the donors and recipients are shown in Table 1. The follow-up period ranged from 3 to 58 months.

\section{Postoperative management}

Fluid, electrolyte and protein losses across the mesh were not significant problems with the use of occlusive wound dressings. All but one of the surviving patients were fed enterally after the immediate postoperative period. Patient number 4 required prolonged parenteral nutrition (8 weeks). The patients were weaned from ventilation according to the usual indications and transferred to the general ward from the intensive care unit (Table 1) after 1-4 days of extubation.

\section{Results \\ Delayed primary closure}

This was achieved in all patients with surviving grafts in one to four stages after 1-7 weeks.

\section{Complications}

There were no complications that could be attributed to the technique. Multiple intestinal perforations requiring 11 additional laparotomies occurred in patient number 4 . but none of the perforations was in the bowel loops in contact with the mesh. In the past, the authors and others: have encountered unexplained multiple intestinal perforations in small recipients of liver grafts in the postoperative period even with immediate primary abdominal closure. The authors therefore believe that this complication was unrelated to the method of closure. In patient number 2 Staphylococcus aureus was grown from a wound swab on day 7 . This infection resolved after 10 days of treatment with oral flucloxacillin. There was no obvious purulent discharge, the mesh was retained and the operative plan was not altered. Therefore, apart from the gut perforations, no serious abdominal infective complications were seen. The wounds have healed well and no incisional hernias have occurred in the five survivors. 
Table 1 Characteristics of patients and grafts where delayed primary closure was used

\begin{tabular}{|c|c|c|c|c|c|c|c|c|c|c|c|}
\hline $\begin{array}{l}\text { Patient } \\
\text { no. }\end{array}$ & $\begin{array}{l}\text { Graft } \\
\text { no. }\end{array}$ & $\begin{array}{l}\text { Recipient } \\
\text { age } \\
\text { (months) }\end{array}$ & $\begin{array}{l}\text { Recipient } \\
\text { weight } \\
\text { (kg) }\end{array}$ & $\begin{array}{l}\text { Donor } \\
\text { age } \\
\text { (years) }\end{array}$ & $\begin{array}{l}\text { Donor } \\
\text { weight } \\
(\mathrm{kg})\end{array}$ & $\begin{array}{l}\text { Graft } \\
\text { type }\end{array}$ & $\begin{array}{l}\text { No. of } \\
\text { stages }\end{array}$ & $\begin{array}{l}\text { ICU } \\
\text { Time in } \\
\text { (days) }\end{array}$ & $\begin{array}{l}\text { Time to } \\
\text { closure } \\
\text { (weeks) }\end{array}$ & $\begin{array}{l}\text { Follow-up } \\
\text { (months) }\end{array}$ & $\begin{array}{l}\text { Fate of } \\
\text { graft }\end{array}$ \\
\hline 1 & & 0.5 & $2 \cdot 3$ & 3 & 14 & & - & - & - & - & \\
\hline 2 & 2 & 6 & $7 \cdot 2$ & 3 & 15 & & 2 & 4 & 3 & 58 & \\
\hline 3 & 3 & 11 & $5 \cdot 5$ & 2 & 12 & & 3 & 30 & 1 & 29 & \\
\hline 4 & 4 & 8 & 6.5 & 10 & 31 & & 4 & 67 & 7 & 14 & \\
\hline & 5 & 8 & 6.5 & 2.5 & 11 & & & 8 & 2 & 13 & \\
\hline 6 & 6 & 7 & 6.5 & 6 & 18 & & - & - & - & - & \\
\hline 6 & 7 & 7 & $7 \cdot 0$ & 3 & 11 & & - & - & - & - & \\
\hline 6 & 8 & 7 & $7 \cdot 0$ & 5 & 28 & & - & - & - & - & \\
\hline 7 & 9 & 11 & 6.5 & 31 & 50 & & 3 & 31 & 7 & 3 & \\
\hline
\end{tabular}

*Patient died from graft infarction secondary to portal vein and hepatic artery thromboses on day 3. †Graft failed on day 1 . $\ddagger$ Graft failed on day 2. \$Patient died from haemorrhagic cerebrovascular accident (CVA) with a viable graft. LLS, left lateral segment; W, whole graft; RTS, right trisegmental graft (with left lateral segment resected); ICU, intensive care unit; HVT, hepatic vein thrombosis; PNF, primary non-function

\section{Survival}

Five of the nine grafts and five of the seven patients have survived with normal graft function.

\section{Causes of graft failure}

Three grafts failed: one due to hepatic vein thrombosis on day 1 , one due to primary non-function on day 2 , and one due to portal vein and hepatic artery thromboses on day 3. Patient number 1 died as a result of the graft failure and patient number 6 died on day 9 from a cerebrovascular accident with a viable graft (Table 1).

\section{Discussion}

Delayed primary closure of the abdominal wall as described has proved to be a useful technique in very small liver graft recipients who are too ill to await a graft of ideal size. As prospective assessment of liver size in cadaveric donors is rarely possible, most paediatric transplant units accept donors who are up to 1.5-2 times the weight of the recipient for whole liver grafts and a recipient:donor weight ratio of up to $1: 5$ or $1: 6$ for reduced-size grafting ${ }^{1,4}$. Although body-weight gives some indication of liver size, the size of segments two and three (together comprising the left lateral segment) varies greatly between donors of the same weight. Use of a simple weight ratio, therefore, may still result in a left lateral segmental graft proving to be too large. In the present group of children, transplantation of whole or reduced livers from much larger donors (ratio up to $1: 8$ ) Was possible without detrimental effects on the graft or compromising the ventilatory ability of the recipient. Wound closure was usually achieved in two to three stages. After placement of the mesh, granulation tissue grew into it causing vascular adhesions of the mesh to the underlying liver and bowel loops. Therefore, frequent clinical assessment of the abdominal tension and ventilation was important to allow these repeated partial closure procedures to be performed as soon as possible. Mesh-related sepsis was not a problem.
In these patients, although it would be possible to cover the skin defect (with or without a mesh in place) with a split skin graft when healthy granulation tissue appears, this would probably result in an inferior cosmetic result.

This technique is based on the assumption that the oversized liver graft will reduce in size to fit the abdominal cavity of the recipient. The ability of the liver to enlarge ${ }^{5,6}$ or shrink ${ }^{6}$ spontaneously to the appropriate size has been particularly well documented in the serial volumetric studies in living related liver transplant recipients reported by Kawasaki et al. ${ }^{6}$. In the present series, the clinical impression of progressive reduction in liver size was substantiated by the ability finally to close the abdomen.

Delayed primary abdominal closure after liver transplantation in small children is feasible, probably because of spontaneous reduction in the graft size over the first few weeks. It is remarkably safe, gives good cosmetic results and may be of benefit in children otherwise at risk of graft infarction because of size disparity.

\section{References}

1 Bilik R, Greig P, Langer B, Superina RA. Survival after reduced-size liver transplantation is dependent on pretransplant status. J Pediatr Surg 1993; 28: 1307-11.

2 Calne RY, Friend PJ, Johnston PS, Jamieson NV. Surgical aspects of liver transplantation. In: Millward-Sadler $\mathrm{GH}$, Wright R, Arthur MJP, eds. Wright's Liver and Biliary Disease, Vol. 2. 3rd ed. London: WB. Saunders, 1992: 1439-56.

3 Marujo WC, Stratta RJ, Langnas AN, Wood RP, Markin RS, Shaw BW Jr. Syndrome of multiple bowel perforations in liver transplant recipients. Am J Surg 1991; 162: 594-8.

4 Otte JB, de Ville de Goyet J, Alberti D, Balladur P, de Hemptinne B. The concept and technique of the split liver in clinical transplantation. Surgery 1990; 107: 605-12.

5 Francavilla A, Zeng Q, Polimeno $L$ et al. Small-for-size liver transplanted into larger recipients: a model of hepatic regeneration. Hepatology 1994; 19: 210-14.

6 Kawasaki S, Makuuchi M, Ishizone S, Matsunami H, Terada $M$, Kawarazaki $H$. Liver regeneration in recipients and donors after transplantation. Lancet 1992; 339: 580-1. 